\title{
КА ПОЕТИЦИ САВРЕМЕНОГ СРПСКОГ ПУТОПИСА - НАГРАДА „ЉУБОМИР П. НЕНАДОВИЋ” ЗА НАЈБОЉА ПУТОПИСНА ОСТВАРЕЊА
}

\begin{abstract}
У раду је сагледано савремено путописно стваралаштво кроз дела награђена Наградом „Љубомир П. Ненадовић”. Анализирана су дела Долина српских кралева, пролећно путоване 2013. Милисава Савића, Koreja post scriptum Радмиле Гикић Петровић, До Оба и Хуангпуа: путописи Љубомира Симовића, Gle!: bedeker jednog lakomislenog Kanta Ласла Блашковића, Ta mjesta: putopisi Стевана Тонтића и Хиландар и Света Гора између мита и историје: nутопис у слици и речи Александра Б. Лаковића. Циљ рада је да кроз анализу награђених књижевних дела оцрта контуре за неку будућу обухватнију поетику савременог српског путописа. Рад покреће питање да ли се може говорити о систематичној поетици савременог путописа из данашње перспективе. Даље проучавање неопходно је проширити увидом у корпус текстова који нису носиоци награде „Љубомир П. Ненадовић”, као и оних који нису објављени као засебне публикације.
\end{abstract}

Къучне речи: путопис, савремена српска књижевност, поетика, Награда „Љубомир П. Ненадовић”

\section{1. Награда „Љубомир П. Ненадовић”}

Одлука да се установи награда „љубомир П. Ненадовић” за најбоље путописно остварење на српском језику донета је 2014. године. Награда је први пут додељена Милисаву Савићу за путопис Долина српских кральев: пролећно путоване 2013. Већ наредне године покренута је манифестација Љубини дани у оквиру које је реализован низ садржаја и програма везаних за уметнички путопис. Награду је 2015. године добила Радмила Гикић Петровић за путопис Koreja post scriptum. Tpeћу годину одржавања манифестације обележио је Љубомир Симовић са делом До Оба и Хуангnуа: nуmописи, а те године покренута је и значајна публикација - алманах Љубини дани. Наредних година награђени су путопи-

1 nevenaa.zivanovic@gmail.com 
си Gle!: bedeker jednog lakomislenog Kanta Ласла Блашковића, Ta mjesta: putopisi Стевана Тонтића и Хиландар и Света Гора између мита и истоpuje: nутопис у слици и речи Александра Лаковића. Године 2020. Награду је добило дело Скице за пловидбу Николе Поповића.

За манифестацију је била значајна одлука да се додела Награде премести у Бранковину, место које и данас негује сећање на Ненадовиће, али и на друге знаметите личности. Промењен је и датум додељивања Награде, те се она сада додељује 14. септембра, на дан рођења Љубомира Ненадовића. Љубини дани и Награда значајни су из више разлога. Награда повезује прошлост и садашњост, негује сећање на Љубомира Ненадовића и прати савремене токове путописне књижевности.

\section{2. Награђена дела}

\section{1. Тематски план путописа}

Награђени путописи обрађују различите теме. Два путописа изричито су усмерена ка националној култури и традицији - Долина српских кралева, пролећно путоваюе 2013. и Хиландар и Света Гора, између мита и историје: путопис у слищи и речи тематизују обилазак српских светиња. Путописац у Долини српских краљева путује долином Рашке и Ибра и обилази манастире, цркве, тврђаве и остале локалитете везане за српску историју и православну религију. Овај путопис одликује мноштво географских података који стварају доживљај веродостојности и објективности, те читалац не сумња да ли се заиста сваки локалитет налази на наведеним „координатама”. Путописац, будући да жели да сачува српску културу и историју од заборава, сматра да је неопходно да да̂ што више прецизних информација.

Поред географских, путопис садржи и историјске податке о изградњи манастира, ктиторима и добротворима, владарима, ратовима, турским нападима и уништавању манастирске заоставштине. Евоцирање давне и славне историје чини дело изузетно сложеним - путописац се не креће само по садашњости, пролећа 2013. године, већ се креће и по давној прошлости. Прошлост покреће многобројна питања, говори нам o „заборављеној цивилизацији и културном благу” (PRODANOVIĆ 2016: 75), о пролазности и пропадању, злој судбини, забораву, неразумевању правих уметничких вредности. Када прави паралелу између прошлости и садашњости путописац заузима критички, полемички тон. Дотиче се питања очувања националног идентитета и културног блага, те у поглављу посвећеном манастиру Ђурђеви ступови констатује:

„Да је био запуштен, види се и по бројним записима, урезаним на зидовима, преко остатака фресака. Има и старих, али и оних од пре четр- 
десетак година. Да се зна да је тог и тог дана пришао грешни тај и тај... Нису само Турци скрнавили манастир, радили су то и Срби, урезујући на фреске своја трошна, пропадљива имена." (SAVIĆ 2014: 286)

Путописац је суров и реалан - не жели да сакрије немар сопственог народа. Он кроз историју преиспитује време у коме живи али и себе. Путовање му помаже да кроз однос појединац: колектив дође до самоспознаје.

У Долини српских кралева преплићу се историјска и митска раван. Путописац износи историјски релевантне чињенице паралелно наводећи и митове везане за посећене локалитете. Увек где постоји простор, он наводи локалне легенде и веровања (нпр. за Петрову цркву наводи веровање да је саграђена на паганском светилишту и да ју је саградио апостол Тит који је познавао Светог Петра - „Прича није ништа друго него легенда" (SAVIĆ 2014: 271)).

Ходочасничко путовање присутно је и у путопису Александра Б. Лаковића, који тематизује обилазак српских светиња на Светој Гори. Релација славна прошлост: недостојна садашњост присутна је на више места у Лаковићевом путопису. Путописац полемичким тоном говори о садашњости и поштовању прошлости. Истиче како људи данас нису достојни славне прошлости и предака, критикује површност савременог човека, похлепу, немар, непоштовање историје и културе. Наводи како су српске светиње, поред тога што су страдале од природних непогода, често биле мета непријатељских напада и скрнављења. Немарно опхођење није евидентирано само од непријатеља, те путописац констатује:

„И никако да се запитамо којих је било више - туђих похара или нашег немара. Пожара и земљотреса или нашег одрицања прошлости. И које су биле погубније. Зато и даље понављамо исте грешке. У последње време, све чешће и чешће. И све теже и теже. Што је неопростиво." (LAKOVIĆ 2018: 78)

Путописац критикује занемаривање националне културе и историје. Прошлост и садашњост су повезане, те он сматра да без поштовања прошлости нема ни светле будућности.

Путопис Александра Лаковића се налази „између мита и историје” што је једна од његових најбитнијих одлика. Граница између историјских чињеница, митова и легенди је флуидна - или прецизније - нема je. Путописање о Светој Гори позива се на оба извора. Тако ће путописац навести: „Будући да из тог периода нема историјских извора, празнине се објашњавају и допуњавају легендама и предањима" (LAKOVIĆ 2018: 125) или супротно: „У причи између легенде и историје, нужно је рећи, да заборав и одсуство убедљивих доказа истину олако претворе у легенду" (LAKOVIĆ 2018: 155). За ходочасника су подједнако битна оба типа информација. 
Ова два путописа имају идентичан однос према прошлости и садашњости. Можемо приметити да имају тенденцију буђења националне свести и очувања културноисторијског наслеђа - критикују немар и краткорочно памћење савременог друштва.

Та мјеста представља путовање једне судбине - путописац свој животни пут започиње у родном крају, наставља га у Сарајеву одакле бива приморан да избегне у Европу. Заокупљен је питањима прошлости и пролазности. Након посете разореном родном крају, констатује: „Nema više ni starih ni mladih, ni pametnih ni ćaknutih u ovom avetinjskom kraju. Nikog i ničeg” (TONTIĆ 2018: 31). Посета родном крају подсећа га на детињство, породицу, сународнике, школу и школске другове. Период ране младости је пун лепих сећања и успомена. Садашњост је другачија: „Sada je na temeljima škole velika gomila kamenja i šuta skrivena rastinjem, a na školskom igralištu podigao je sebi krov nad glavom čovjek iz propale gazdinske kuće pri obližnjoj šumi” (TONTIĆ 2018: 28). Путописац говори и о историјским дешавањима и њиховој пројекцији на његов живот. Ратне тематике се дотиче и Ласло Блашковић у путопису Gle!: bedeker jednog lakomislenog Kanta - у поглављу посвећеном посети Босни и Херцеговини говори о страхотама које су остале након ратова („Za šta bi se čovek mašio, ostavilo bi prljavi, krvav trag. Bilo je sve odvratno, ma ko da je za to bio kriv" (BLAŠKOVIĆ 2016: 80)). Поред Босне и Херцеговине, путопис обухвата многе друге дестинације - Русију, Азербејџан, Швајцарску, Немачку, Чешку, Мађарску, Грчку, Бугарску, Словенију, Македонију, а последњих неколико поглавља посвећено је родном крају - Новом Саду, али и Смедереву и Вршцу, те путописац, „лакомислени Кант”, индиректно указује на нераскидиву повезаност са својом средином. Путопис Koreja post scriptum Радмиле Гикић Петровић посвећен је периоду живота списатељице у Јужној Кореји, док у путопису До Оба и Хуангпуа путописац тематизује посету Русији и Кини. Сви ови путописи се дотичу историјских, политичких, културних, књижевних тема у складу са иманентним поетикама аутора.

\section{2. Ми и други - култура и обичаји}

Путописци истичу сличности и разлике између своје и друге културе, некада чак и пореде различите културе и поводом тога износе своје ставове. Приметне су релације ми: они (други). Културна размимоилажења, односно другачије поимање одређених ентитета, присутна су у Симовићевом путопису До Оба и Хуангпуа:

„Све време током разговора, кад год би неко употребио речи 'запад' и 'западно', долазило је до неспоразума. Ми смо веровали да они, кад 
кажу 'запад', мисле, као ми, на Немачку, Француску, Италију, Шпанију, Енглеску. Они, међутим, појмом 'запад’ означавају Совјетски Савез западно од Урала! Њима је запад оно што је нама исток." (SIMOVIĆ 2017: 39, 40)

У наведеном цитату се примећује другачије просторно перципирање стварности. Средиште интересовања у путопису Koreja post scriptum Радмиле Гикић Петровић представљају две земље, Србија и Кореја. Примећујемо поређење култура и постојање релација Србија: Кореја. Путописац „не пропушта ниједну прилику да покаже шта је све у Кореји другачије” (MIKIĆ 2016: 28), а то се може илустровати следећим примерима: „Inčon je velik grad, sagrađen 1883. godine, u njemu živi samo tri miliona ljudi, za nas mnogo, za njih prosečno”, „oni već na rođenju deteta računaju jednu godinu, i Sin se nekako ubacivao i tamo gde mu nije mesto", „Tu smo odlazili da sa Seliksonom proslavimo dan posvećen drveću, sećaš se te slike, kako je bilo nama čudno i veselo da gledamo kako Korejci grle stabla, šire ruke, na koru naslanju obraze i u nebo gledaju" (GIKIĆ PETROVIĆ 2014: $49,68,207)$. Наведени примери илуструју културне разлике на релацији ми: они (број становника, другачије рачунање година детета, другачији обичаји и празници). Путописац проналази и сличности: „I u Koreji se, za vreme svečanosti Kimjang, žene okupljaju, šale i razgovaraju, kao i mi ovde, one tamo prave kimči, mi, eto, ajvar”, „Venci crvene paprike na svakom koraku u starinskim delovima grada, u predgrađima i po selima, uveliko podsećaju na pojedine naše predele, gde se na dovratku kuće mogu videti nanizani venci” (GIKIĆ PETROVIĆ 2014: 194, 201). Акценат је ипак више стављен на разлике између корејске и српске културе коју путописац истиче кроз разговоре са драгим људима. Људи из окружења означени су као Мој Братанац, Моја Тањушка, Брат Вајар, Моја пријатељица винарка из Буковца и сл. Коришћењем личне заменице мој/ моја директно се наглашава личан, присан однос списатељице и људи са којима она дели своја искуства из Kopeje.

Путописац, опчињен Корејом и животом у Сеулу, у многим аспектима Кореју ставља изнад Србије (у питању су неки обичаји, географски предели и сл.). У разговору са пријатељицом ауторка истиче: „Evo, ti koja si srasla s prirodom, kažem ti da su od bukovačkih padina lepše Kurjong sa (sa = planina) i Čikasan (park)” (GIKIĆ PETROVIĆ 2014: 79). Такође, примећује се благо потцењивање људи који не деле њено интересовање и опчињеност Корејом. У писму Братанцу наводи „šta ti, koji sediš u Karlovačkoj gimnaziji i udaraš po tipkama klavira, šta ti znaš o muzici u Koreji? Ništa ti ne znaš o korejskoj pevačici i bubnjevima” (GIKIĆ PETROVIĆ 2014: 169). Одушевљеност корејском културом и обичајима иде до присвајања туђих културних образаца, зато што су на приповедачевој скали 
ми: они - „они” примарнији (у неким сегментима). Ова тврдња се може илустровати следећим цитатом: „Izgleda da me jedino otac sluša, Brat nudi rakiju, i ja mu kažem da to mora da radi obema rukama, kao u Koreji. I da sebi ne može da sipa, nego da to uradi neko pored njega" (GIKIĆ PETROVIĆ 2014: 196). Примењен је занимљив приповедачки поступак, дешавања у садашњости подсећају путописца на Кореју и њене обичаје. Читаоцу је омогућено да се упозна са животом у Кореји, али и да сагледа специфичности земље из које путописац полази и у коју се враћа.

Занимљиво је шта се сматра егзотичним ${ }^{2}$ у различитим културама. У писму пријатељици путописац наводи: „Znaš, pišem Tanjuški, da je majka Kim Đi Hjang želela da joj sve tri kćerke studiraju nešto egzotično, tako da se jedna upisala na kineski, druga na nemački, a Kim Đi Hjang na srpski jezik" (GIKIĆ PETROVIĆ 2014: 160). У сусрету две различите културе примећује се различит доживљај егзотичног - егзотично је оно што је страно, другачије. У наведеном примеру се, поред кинеског и немачког језика, српски језик сматра егзотичним.

\section{3. Одређење насловом. Жанровски полиморфизам}

Награђеним путописима је заједничко одређење насловом. Само путопис Радмиле Гикић Петровић у наслову нема упућивање на путовање и путописну књижевност. Остали путописи већ самим насловом развијају код читаоца одређен хоризонт очекивања.

Жанровско одређење савремених путописа веома је комплексно. Ова дела се жанровски одређују као путописи, али она у себи садрже и елементе писма, дневника, есеја, научне студије. Долина српских краљева је специфично и жанровски разуђено дело, оно „стоји између путописа, историје уметности и филозофско-антрополошког трактата” (PRODANOVIĆ 2016: 74). Писање о неимарству и уметности фрескосликарства незаобилазни су када је у питању обилазак српских светиња. Поред многобројних фотографија фресака, путописац прилаже и своја тумачења и импресије. Он се детаљно удубљује у посматрање, анализирање и уживање - застаје пред сваком фреском, посматра сваки детаљ. Примећује линије, прелазе, боје ${ }^{3}$. Његов доживљај фресака лежи управо

2 Егзотизам је „тенденција која се јавља у европској књижевној традицији да се описују мотиви, људи и предели из далеких земаља, било да су аутори те крајеве посетили или да се ради о производу њихове маште”, такође „егзотизам може бити одређен и као посебно стање, као нешто што је страно, несвакидашње, отуђујуће” (BEČANOVIĆ NIKOLIĆ 2011: 95, 96).

3 За боје на фрескама у Сопоћанима путописац наводи: „Овде се боја одваја од оног што приказује, постаје самостална, и показује за какве је све игре способна: игре прелива, сенчења, титраја. Овде је боја у вечитом покрету, узбурканом, немирном. Овде је исписана највећа похвала боји" (SAVIĆ 2014: 323). 
у динамици коју стварају боје. Неке фреске покрећу његову уметничку имагинацију, те он даје своја тумачења приказаног.

Из целог путописа се примећује да путописац искрено ужива у средњовековној уметности. Поред тога што неретко трага за скривеним значењима у фрескама, он је упознат и са историјским развојем фрескосликарства - познато му је у ком периоду је који стил био доминантан, који сликари су важили за најбоље. Занимљиво је спајање религијских тема и портрета са обичним људима и свакодневним животом. Примећује како су иконе и фреске често рађене по узору на људе из тог краја: „Мали Христ, буцмастих образа и знатижељног погледа, личи на мусавог дечачића, кога можете срести у овим селима” или „Исус Христос је носати, великог чела, крупних очију, одлучног погледа. Копаоничка мушкарчина" (SAVIĆ 2014: 224). Ови цитати додатно илуструју путопишчев специфичан доживљај фресака виђених на путовању. У посматрање и тумачење фресака путописац уводи и своје читаоце, обраћајући им се у другом лицу множине - за фреску у манастиру Нова Павлица наводи: „Погледајте Богородичине усне, доњу посебно” (SAVIĆ 2014: 177). Овим металептичким прекорачењима омогућава се већи степен урањања приликом читања.

Путописац критички посматра фреске, те доноси закључке о томе да ли је реализација успешна или не. У манастиру Стара Павлица приметио је проблем у незграпном цртању животиња (коња), а то је документовао и фотографијама. У више манастира је уочио проблем приликом сликања руку. Лице, одежда и положај тела били су добро насликани, али не и руке. Примећује се да путописац без устезања наводи добре и лоше стране фрескосликарства у посећеним манастирима.

Хиландар и Света Гора, између мита и историје: путопис у слиuзи и речи може се, као и Долина српских краљева, сматрати похвалом уметности, пре свега фрескосликарству, иконама и архитектури.

Koreja post scriptum је „путописно дело које има и обележја и неких других књижевних врста, пре свега оних који се везују за уметност причања прича” (МIKIĆ 2016: 28). Овај путопис је „морфолошки јако сложено дело” засновано на „укрштању путописних и приповедачких елемената" (MIKIĆ 2016: 26). Приповедни поступци се динамично смењују кроз поглавља, при чему су нека конципирана у форми писма сину, белешке о местима која се обавезно морају обићи у Сеулу... Поглавље „Златна десетка - улицама Сеула” осмишљено је као дијалог који воде путописац/ приповедач и брат (Мој Брат, Вајар, Мој Брат Вајар); описане су знаменитости Сеула кроз форму условних реченица, потенцијал + да + перфекат: „Da si došao, obišao bi sa nama ceo Seul”, „Da si došao kod nas u Seul, pokazala bih ti kako je moguće da ceo dan provedeš u gradu, a da grad 
i ne vidiš" (GIKIĆ PETROVIĆ 2014: 56, 64). Овај занимљив приповедачки поступак у оквиру кога би се могло говорити о виртуелном наративу, укључује и реплике саговорника, те приповедање чини динамичним.

Путопис До Оба и Хуангпуа подељен је на два дела - „Руске цркве и реке” и „Кина: читање спаљених књига”. Доживљаји и рефлексије са пута у Русију и Кину исказане су у дневничкој форми. Такође је и у делу Gle!: bedeker jednog lakomislenog Kanta Ласла Блашковића део поглавља о Аустрији уобличен кроз дневничку форму. У Блашковићевом делу импресије са путовања нису примарне - путописца виђено само подстиче да проговори о нечему другом. Посета Чешкој у путописцу буди асоцијацију на Кафку, преко кога се долази до Александра Тишме и романа Употреба човека. Чешка је само повод да се проговори о нечему другом. Поглавље у коме се анализира Употреба човека писано је у стилу научног рада. Путопис повремено добија облике филозофског трактата или есеја, на моменте прераста у роман па се може говорити и о путописцу и о приповедачу. На почетку дела путописац се чак дотиче и теорије књижевности, позива се на стручну литературу али сагледану кроз призму сопствене поетике.

Награђена дела, поред прозних деоница, инкорпорирају и поезију. Ta mjesta: putopisi представљају жанровски комплексно дело, писано у прози и стиху. Песме прате прозу на тематско-мотивском и идејном плану. Путописац понекад поетско изражавање ставља изнад прозног седам дана у Јерусалиму не могу се описати речима („nemam namjeru niti mogu da opisujem” (TONTIĆ 2018: 128)), а за посету Христовом гробу наводи: „О tome sam mogao da napišem samo - pjesmu” (TONTIĆ 2018: 128). Утиске из Јерусалима не може предочити реченицама, прозним текстом, те у помоћ призива поезију. Путопис некада има облик дневничког записа. Поглавље „Magla ispod olimpijskih planina” писано је у форми дневника вођеног од 16. до 22. фебруара 2007. године. Путописац говори о својим свакодневним активностима, али оне нису у првом плану. Важнија су његова размишљања о уметности, политици, ратним и поратним дешавањима. Он стиче утисак да су се Олимпијске игре 1984. године одиграле на некој другој, срећнијој планети, а не у Сарајеву. Свуда је магла - „Tmuran dan, kao i juče. Slavna bosanska magla oko nas, u nama” (TONTIĆ 2018: 76). Приповедање у овом поглављу је у првом лицу једнине, а дневничка форма омогућава путописцу да буде субјективан. Поглавље „Rajnsberški melanž” осмишљено је као транскрипција телефонског разговора. Путописац на самом почетку истиче: „Već sam pomišljao da sam najzaboravljeniji čovjek na svijetu, kad je zazvonio i moj telefon" (TONTIĆ 2018: 139) - ова реченица је мотивација за нови приповедачки поступак. Кроз телефонски разговор два пријатеља долазимо до информација како 
је путописцу у Рајнсбергу.

Савремени путопис одликује жанровски полиморфизам и склоност жанровским експериментима. У складу са модерним теоријама жанрова, ова путописна дела ћемо најчешће одређивати описно ${ }^{4}$.

\section{4. Савремени српски путопис и визуелне уметности}

Савремени путописи често поред текстуалног дела садрже и продукте визуелних уметности. Стефани Лич (Stephanie Leitch) истиче постојање „визуелних слика” (visual images) у путописној књижевности - овде спадају фотографије, скице, илустрације и сл. Овакве творевине су битни делови књиге, улепшавају и детаљније илуструју причу, чак и привлаче потенцијалне купце књиге (самим тим и читаоце). Оне су доказ веродостојности написаног, те поред уметничке могу имати и документарну вредност (LIČ 2019: 456). Неки од награђених путописа садрже фотографије. У Долини српских краљева фотографије су у већини случајева аматерске али са смислом за детаљ и боје. Ауторска су дела путописца (Милисава Савића). У поглављу посвећеном манастиру Жича он истиче:

„Свестан сам да у мојим фотографијама има доста аматеризма, али је једно сигурно: снимци нису нашминкани. Камера је често хватала детаље које види обичан ходочасник, какав сам ја. Историчар уметности би сигурно усмерио објектив у неком другом правцу, избегавајући многе свакодневне предмете (боце с вином и зејтином, папирнати новац и слично), којих има нарочито у мањим, сеоским црквама." (SAVIĆ 2014: 18)

Фотографије „причају” причу, или, још прецизније: у функцији су илустровања и допуне текстуалног дела путописа. Имају уметнички али и документарни значај, те је створен утисак веродостојности и тачности. Поред фотографија, путопис садржи и две мапе. Оне се налазе на корицама на почетку и крају књиге, на српском и на енглеском језику. Мапе приказују долину Ибра и Рашке и на њима су обележени сви манастири, цркве, тврђаве и градови које је путописац обишао. Бројевима су означена сва посећена места, почев од манастира Жиче до Цркве Св. Петра и Павла у Тутину, која је обележена бројем шездесет пет. Ова два локалитета представљају почетну и завршну тачку путовања, а између њих се налазе Студеница, Градац, Петрова црква, Ђурђеви ступови, Сопоћани, Бањска, Црна Река, градови Звечан, Рас, Јелеч, многобројне цркве и манастири по малим селима. Мапе помажу у оријентацији и праћењу

4 „Izvesno, moderna teorija žanrova je opisna. Ona ne ograničava broj mogućih vrsta i autorima ne propisuje pravila. Njena je pretpostavka da se tradicionalne vrste mogu 'pomešati' i dati novu vrstu" (VELEK i VOREN 1974: 282). Насупрот њој је класична теорија која је против жанровских укрштања. 
путопишчеве маршруте и, као и фотографије, допуњавају текст. Оне су саставни део путописа.

Фотографије у путопису Александра Б. Лаковића дела су Рајка Каришића, Горана Вељковића и Мирослава Јеремића. Фотографишући Свету гору - манастире и природу која их окружује - они су успели својим фотографијама да пренесу аутентичну атмосферу древности и нестварности која обузима ходочасника, те са разлогом у наслову дела стоји одређење - „путопис у слици и речи”. Уметничке фотографије присутне су и у путопису Ласла Блашковића. Интересантан је податак да се у путописима Милисава Савића и Ласла Блашковића налази и неколико фотографија самих аутора, што покреће питање разликовања аутора и путописца. Ова дистинкција се често преиспитује у литератури, те неки проучаваоци праве разлику између писца и путописца, а неки не праве.

\section{5. Критика туризма}

У путописима је приметан критички однос према туризму. Путописац у делу До Оба и Хуангпуа сматра да је модерни туризам површан и неозбиљан: „На пространом тргу црне се бројне групице туриста, који, окупљени око својих водича и њихових заставица, с ногу, као брзу храну, добијају и гутају порцију уобичајених информација” (SIMOVIĆ 2017: 55). Критички је настројен према туристима и њиховим водичима, те туризам у оваквом облику сматра површним и недостојним:

„Тамо где су се некад, над главама коњаника, наоружаних луковима и стрелама, вијориле заставе од јаковог репа, уплетене с белом свилом и украшене перјем, сада се виде заставице туристичких водича, око којих се, да се не изгубе, окупљају групице туриста, наоружаних бедекерима и камерама." (SIMOVIĆ 2017: 58)

Овај пример такође илуструје површност туриста, али се дотиче и пролазности - прави се паралела између прошлости и садашњости, где се на прошлост гледа као на славно, херојско доба. Кроз контраст (вијорење ратних „застава”: вијорење „заставица” туристичких водича) примећује се критика савремених, комерцијалних путовања.

Путописац у последњем поглављу дела Koreja post scriptum жели да обиђе одређене знаменитости али добија одговор: „To je turističko mesto, šta ćemo tamo, govori Moj Muž, mršti se dok ginseng čaj pije. To je mesto gde pomodari idu, idu bogati Korejci, šta će to nama?" (GIKIĆ PETROVIĆ 2014: 216). Дистинкција путник: модерни туриста присутна је у путописима савремене српске књижевности, и није новина, будући да је и у ранијим књижевним периодима приметан негативан став према туризму ${ }^{5}$.

5 О негативној критици туризма су писали Слађана Јађимовић (Путописи српске 


\section{6. Интертекстуалност}

Савремене српске путописе одликује интертекстуалност. Сва награђена дела садрже цитате и алузије на друга дела. Ово упућивање може се односити и на ранија уметничка дела која тематизују одређену дестинацију (путописац истиче ко се пре њега интересовао за одређену земљу). Припремајући се за предстојећи пут, путописац у делу До Оба и Хуангпуа спомиње читање литературе на српском језику о Кини, те не изоставља дело „Кина - око на путу” Миодрага Павловића и песме Васка Попе (SIMOVIĆ 2017: 48, 49). Долази до закључка:

„Тако су ми, и много пре поласка у Кину, и очи и уши биле препуне кинеских слика и звукова, људи, пејзажа, градова, бојних поља, планина и река, мостова, павиљона са фењерима и фењера који се огледају у рибњацима. Већ је и само усредсређено читање било нека врста путовања." (SIMOVIĆ 2017: 51)

Путовање не мора нужно бити везано за реалан одлазак на пут, већ се може путовати захваљујући литератури и књигама. Ова констатација истиче значај књижевности и њених могућности.

Дело До Оба и Хуангпуа садржи велики број цитата и алузија на друга уметничка дела. Михајло Пантић истиче да на високе естетске домете овог дела утиче и „сајџијски прецизно умрежавање властитог текста у свет поезије, свет књижевности, потом и свеколике уметности. Где год да се обрео, и шта год да му се збило или приснило, Симовић то учвршћује и богати позивањем на неки (уметнички) артефакт" (PANTIĆ 2017: 103). Путописац цитира стихове песме „Смрт Жукова” Јосифа Бродског на које су га подстакле знаменитости Русије, шетња Црвеним тргом покреће размишљања о песми Осипа Мандељштама, посета Сибиру путописца подсећа на роман Злочин и казна и на Раскољниковљево робијање, када пише о Великом зиду не изоставља песму Сунг Вуа „Битка јужно од великог зида” и Чјен Ци Сеа „Бедем код Као Јуа” и сл. Успостављене интертекстуалне мреже представљају надовезивање на књижевну традициjу. До цитираних дела се углавном долази асоцијативно и најчешће имају естетску функцију.

Долина српских кралева прожета је интертекстуалним мрежама. Путописац путује сам у реалном простору и времену, али није сам у духовним сферама. То наводи у уводу - у мислима и машти је путовао са многим писцима од којих су неки пре њега ходочастили долином Ибра и Рашке и оставили значајна уметничка дела (SAVIĆ 2014: 6). У Расу се присећа стихова Слободана Ракитића и са њим успоставља дијалог:

авангарде), Владимир Гвозден (Српска путописна култура 1914-1940. Студија о хронотопичности сусрета) и други. 
„Много шта је, мој драги Слободане Ракитићу, не само овде у Расу, већ и у целој долини српских краљева, као из друге приче” (SAVIĆ 2014: 305), Црна Река буди у њему књижевне асоцијације на Григорија Божовића и Драгишу Бојовића („О манастиру врло лепо писао је познати приповедач Григорије Божовић” и „На трагу Божовића лепу књигу о историји, фрескама и иконостасу Црне Ријеке написао је песник и медиевалист Драгиша Бојовић” (SAVIĆ 2014: 369)).

Долина српских краљева садржи и позивање на дела народне књижевности. У Новој Павлици путописац се сећа епске народне песме о Стефану Мусићу („У познатој народној песми Стефан Мусић преспавао је полазак на Косово Поље, али он ипак стиже при крају битке и, свакако, гине" (SAVIĆ 2014: 170)). Приликом посете манастиру Бањска у њему се пробудило сећање на епског јунака Бановић Страхињу и истоимену песму.

Путопис Gle!: bedeker jednog lakomislenog Kanta одликује „путовање" путописца кроз књижевна дела и непостојање разлике између света књижевности и свакодневног, реалног живота. Некада се на цитатност директно указује („Nije, gospođo, uveravam vas, 'on je već desetljeće mrtav' (iznenada shvatam da u tom času citiram Ujevićev precizni stih)" (BLAŠKOVIĆ 2016: 89, 90)). У наведеном примеру цитиран је Тин Ујевић и то је недвосмислено истакнуто. Цитатност је негде обележена курзивом $^{6}$, али није правило:

„U Direnmatovoj biblioteci, dok sam prebirao po njegovim knjigama, 'blago, rukom', ne slušajući glas udivljenog, merkantilnog kustosa [...] setio sam se satirske igre Direnmatove, koja pobija ovlašni pogled našeg savremenog Nušića"

(BLAŠKOVIĆ 2016: 13).

Доживљај библиотеке Фридриха Диренмата путописац богати речима из „Суматре” Милоша Црњанског. Овакав поступак доказује да за путописца нема разлике између књижевног и некњижевног света. Ова два света су у његовој свести једно 7 . Навешћемо још неке примере цитатности: „Elem, do pre koju godinu vozio sam slovenački, 'tomosov', nebeskobeli minibicikl, iskrivljenog kormana, bez blatobrana, sa sedlom od marame i uzdom od kanapa" (BLAŠKOVIĆ 2016: 49) - у наведеном цитату путописац се позива на стихове песме Јована Јовановића Змаја, „Мали коњаник”, те на овај начин духовито жели да опише какво је било његово превозно сред6 У раду, из техничких разлога, наводницима.

7 Радивоје Микић, говорећи о цитатности у Блашковићевом путопису, наводи: „Блашковић, као и у много других случајева, жели да покаже да за њега књижевни свет није одељен од стварног света неком непрелазном границом, већ да се та два света спајају и бивају једно у свести онога ко је изабрао да баш у њима једнако аутентично постоји" (MIKIĆ 2017: 16). 
ство. Када пише о Југославији за Југословене наводи: „izgubili se negde, u kući smeha i zaborava, ili u supermarketu, ako slušate starostavne pankere" (BLAŠKOVIĆ 2016: 72). У овом цитату алудира на дело Књига смеха и заборава Милана Кундере који је био изузетно читан у Југославији и на песму „Lost in the supermarket” панк-рок бенда The Clash. Интертекстуалне мреже у делу су некада скоро неприметне, те би се додатним тумачењем и проучавањем могло издвојити са којим све делима је успостављена релација.

\section{7. Књижевни национализам и књижевни космополитизам}

Јован Деретић у књизи Пут српске књижевности: идентитет, границе, тежюе истиче постојање два обележја српске књижевности књижевни национализам и књижевни космополитизам. Књижевни национализам подразумева испољавање „националног, етничког, политичког, државног и културног идентитета српског народа” (DERETIĆ 1996: $230)^{8}$ а књижевни космополитизам „обухвата све облике отворености према страном свету и туђим културама” (DERETIĆ 1996: 230). Ове две традиције смењују се, а преовлађивање једне не искључује другу. Постојање ових обележја примећујемо у српској путописној књижевности - у сваком од награђених путописа преовлађује једна тенденција, иако је увек присутна и друга. У путописима који тематизују ходочасничка путовања доминантан је књижевни национализам. Koreja post scriptum примарно је усмерена ка књижевном космополитизму, мада се примећује и присуство књижевног национализма. Преплитање ових обележја присутно је и у осталим награђеним путописима. Из данашње перспективе тешко је одредити које обележје је доминантније у путописној књижевности ${ }^{9}$.

\section{3. Закључак}

Савремена путописна дела, носиоци Награде „Љубомир П. Ненадовић”, имају заједничких одлика и извесних поетичких укрштања. Неке од одлика су жанровска хибридност, интертекстуалност, заокупљеност сличним темама заснованим на друштвено-политичким дешавањима, критички став према масовном туризму, присуство продуката визуелних уметности и сл. Путописи се и разликују, зависно од иманентних поетика путописаца.

Остаје отворено питање да ли можемо говорити о систематич-

8 Књижевном национализму се може приступити директно кроз књижевна дела, или индиректно, кроз књижевна и културна збивања (DERETIĆ 1996: 230).

9 Неопходно је проширити корпус грађе и на друга путописна дела како би се дошло до прецизнијих закључака. 
ној поетици савременог путописа из данашње перспективе. У раду је дат нацрт за будућу, свеобухватнију поетику савременог српског путописа. Она би се морала заснивати на обимнијем корпусу грађе који би подразумевао и дела која нису носиоци Награде, као и дела која нису објављена као засебне публикације, већ се налазе у периодици.

\section{Цитирана литература}

BEČANOVIĆ NIKOLIĆ 2011: BEČANOVIĆ NIKOLIĆ, Zorica [i dr.]. Pregledni rečnik komparatističke terminologije u književnosti i kulturi. Novi Sad: Akademska knjiga, 2011. [orig.] БЕЧАНОВИЋ НИКОЛИЋ, Зорица [и др.]. Прегледни речник компаратистичке терминологије у књижевности и култури. Нови Сад: Академска књига, 2011.

DERETIĆ 1996: DERETIĆ, Jovan. Put srpske književnosti: identitet, granice, težnje. Beograd: Srpska književna zadruga, 1996. [orig.] ДЕРЕТИЋ, Јован. Пут српске кюижевности: идентитет, границе, тежне. Београд: Српска књижевна задруга, 1996.

LIČ 2019: LEITCH, Stephanie. „Visual Images in Travel Writing”. The Cambridge History of Travel Writing, Cambridge: Cambridge University Press. <https:// www.academia.edu/39509692/Visual_Images_in_Travel_Writing >

doi: $10.1017 / 9781316556740.030$

MIKIĆ 2016: MIKIĆ, Radivoje. „Koreja post scriptum’ Radmile Gikić Petrović, beseda na dodeli nagrade". Ђубини дани: алманах истоимене манифестаиије и Награде 'Ђубомир П. Ненадовић', god. 1, broj 1 (2016): 26-28. [orig.] МИКИЋ, Радивоје. „'Koreja post scriptum' Радмиле Гикић Петровић, беседа на додели награде”. Љубини дани: алманах истоимене манифестације и Награде 'љубомир П. Ненадовић', год. 1, број 1 (2016): 26-28.

MIKIĆ 2017: MIKIĆ, Radivoje. „Nagrada 'Ljubomir Nenadović”. Ljubini dani: almanah istoimene manifestacije i Nagrade 'Ljubomir P. Nenadovic', god. 2, broj 2 (2017): 14-17. [orig.] МИКИЋ, Радивоје. „Награда 'Љубомир Ненадовић”. Љубини дани: алманах истоимене манифестације и Награде ‘Љубомир П. Ненадовић’, год. 2, број 2 (2017): 14-17.

PANTIĆ 2017: PANTIĆ, Mihajlo. „Pesnički putopis Ljubomira Simovića”. Do Oba $i$ Huangpua: putopisi/ Ljubomir Simović - 2. izdanje. Beograd: Tanesi, 2017. [orig.] ПАНТИЋ, Михајло. „Песнички путопис Љубомира Симовића”. До Оба и Хуангпуа: путописи/ Љубомир Симовић - 2. издање. Београд: Танеси, 2017.

PRODANOVIĆ 2016: PRODANOVIĆ, Ostoja. „Putopisna produkcija u godinama 2014-2016". Ljubini dani: almanah istoimene manifestacije i Nagrade 'Ljubomir P. Nenadović', god. 1, broj 1 (2016): 71-81. [orig.] ПРОДАНОВИТ, Остоја. „Путописна продукција у годинама 2014-2016”. Љубини дани: алманах истоимене манифестације и Награде 'љубомир П. Ненадовић', год. 1, број 1 (2016): 71-81.

VELEK i VOREN 1974: VELEK, Rene i Ostin VOREN. Teorija književnosti - preveli 
Aleksandar I. Spasić (I, II i III deo), Slobodan Đorđević (IV deo) - 2. izdanje. Beograd: Nolit, 1974.

\section{Извори}

BLAŠKOVIĆ 2016: BLAŠKOVIĆ, Laslo. Gle!: bedeker jednog lakomislenog Kanta. Beograd: Službeni glasnik, 2016.

GIKIĆ PETROVIĆ 2014: GIKIĆ PETROVIĆ, Radmila. Koreja post scriptum. Sremska Kamenica: Orion spirit, 2014.

LAKOVIĆ 2018: LAKOVIĆ, Aleksandar B. Hilandar i Sveta Gora, izmedu mita i istorije: putopis u slici i reči. Raška: Centar za kulturu, obrazovanje i informisanje Gradac; Kragujevac: Duhovni lug, 2018. [orig.] ЛАКОВИЋ, Александар Б. Хиландар и Света Гора, између мита и историје: путопис у слици u речи. Рашка: Центар за културу, образовање и информисање Градац; Крагујевац: Духовни луг, 2018.

SAVIĆ 2014: SAVIĆ, Milisav. Dolina srpskih kraljeva: prolećno putovanje 2013. Beograd: Društvo Raška škola, 2014. [orig.] САВИЋ, Милисав. Долина српских кралева: пролећно путоване 2013. Београд: Друштво Рашка школа, 2014.

SIMOVIĆ 2017: SIMOVIĆ, Ljubomir. Do Oba i Huangpua: putopisi - 2. izdanje. Beograd: Tanesi, 2017. [orig.] СИМОВИЋ, Љубомир, До Оба и Хуангnуа: nутописи - 2. издање. Београд: Танеси, 2017.

TONTIĆ 2018: TONTIĆ, Stevan. Ta mjesta: putopisi. Novi Sad: Agora, 2018. 
Nevena S. Živanović

\section{TO POETICS OF CONTEMPORARY SERBIAN TRAVELOGUE - „LJUBOMIR P. NENADOVIĆ” PRIZE FOR THE BEST TRAVELOGUES}

In this paper is the contemporary travel writing is perceived through travelogues that won „Ljubomir P. Nenadovic” Prize. Corpus of structure consists of travelogues The Valley of Serbian Kings, A Spring Joerney 2013 by Milisav Savic, Korea Post Scriptum by Radmila Gikic Petrovic, To Ob and Huangpu: travelogues by Ljubomir Simovic, Behold!: Travelogue of one reckless Kant by Laslo Blaskovic, Those places: travelogues by Stevan Tontic and Hilandar and Mount Athos, between myth and history: travelogue in pictures and words by Aleksandar B. Lakovic. The aim of this paper is a draft for forming of future more comprehensive poetics of the contemporarry Serbian travelogue through analysis of award winning travelogues. The paper has the question - can we speak about systematic poetics of contemporary Serbian travelogue from today's perspective. It is necessary to expand corpus of structure to travelogues that didn't win „Ljubomir P. Nenadovic” Prize and to travelogues who aren't published as separate publications.

Keywords: travelogue, contemporary literature, poetics, „Ljubomir P. Nenadović” Prize 